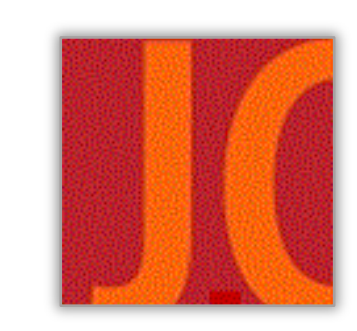

\title{
Kizhay Ottiziwin: To Walk With Kindness and Kinship
}

\author{
Vicki Kelly \\ Simon Fraser University
}

\begin{abstract}
:
Forty years ago, I was sitting beside Poohbah Lake, a part of my homeland. I was deeply engaged in a process I would now describe as attunement and prayer; I was asking Gzhwe Mnidoo and the Ancestors to guide me on my way. I longed to be a living being of kindness and useful to Creation by honouring my kinship to A/l My Relations. As my moccasined feet gently walked the land, I wanted to honour each and everything as created, to open my heart, and to regard each being with reverence and respect. I learned to hold these teachings as they were offered. As I grew older, I understood the enormous gift I was given to witness Creation as it had been created by Gzhwe Mnidoo. This learning legacy seared itself into my heart and spirit. As I wander my life journey I return to the teachings of my people, the Anishinaabe. I continue to seek an honourable way to walk. This Indigenous Métissage tells the story of my search for Mino Bimaadiziwin through the practice of Kizhay Ottiziwin.
\end{abstract}

Keywords: Anishinaabe teachings; Indigenous education; walking pedagogy; Mino Bimaadiziwin; Kizhay Ottiziwin 


\section{Kizhay Ottiziwin : \\ marcher avec la gentillesse et la parenté}

\section{Résumé :}

Il y a 40 ans, j'étais assis au bord du lac Poohbah, une partie de ma terre natale. J'étais profondément engagé dans un processus que je décrirais maintenant comme une harmonisation et une prière ; je demandais à Gzhwe Mnidoo et aux ancêtres de me guider sur mon chemin. J'avais envie d'être un être vivant de gentillesse et utile à la création en honorant ma parenté avec toutes mes relations. Tandis que mes mocassins parcouraient doucement la terre, je voulais honorer tout un chacun et tout comme comme étant une création, ouvrir mon cœur et considérer chaque être avec révérence et respect. J'ai appris à tenir ces enseignements tels qu'ils étaient offerts. En vieillissant, j'ai compris l'énorme don qui m'était offert pour assister à la création telle qu'elle avait été créée par Gzhwe Mnidoo. Cet héritage d'apprentissage s'est gravé dans mon cœur et mon esprit. En parcourant le chemin de ma vie, je reviens aux enseignements de mon peuple, les Anishinaabe. Je continue à chercher une manière honorable de marcher. Ce métissage autochtone raconte l'histoire de ma recherche de Mino Bimaadiziwin à travers la pratique de Kizhay Ottiziwin.

Mots clés : les enseignements anishinaabe; l'éducation autochtone; la pédagogie de la marche; Mino Bimaadiziwin; Kizhay Ottiziwin 


\section{Reaching Back: People of the Seventh Fire}
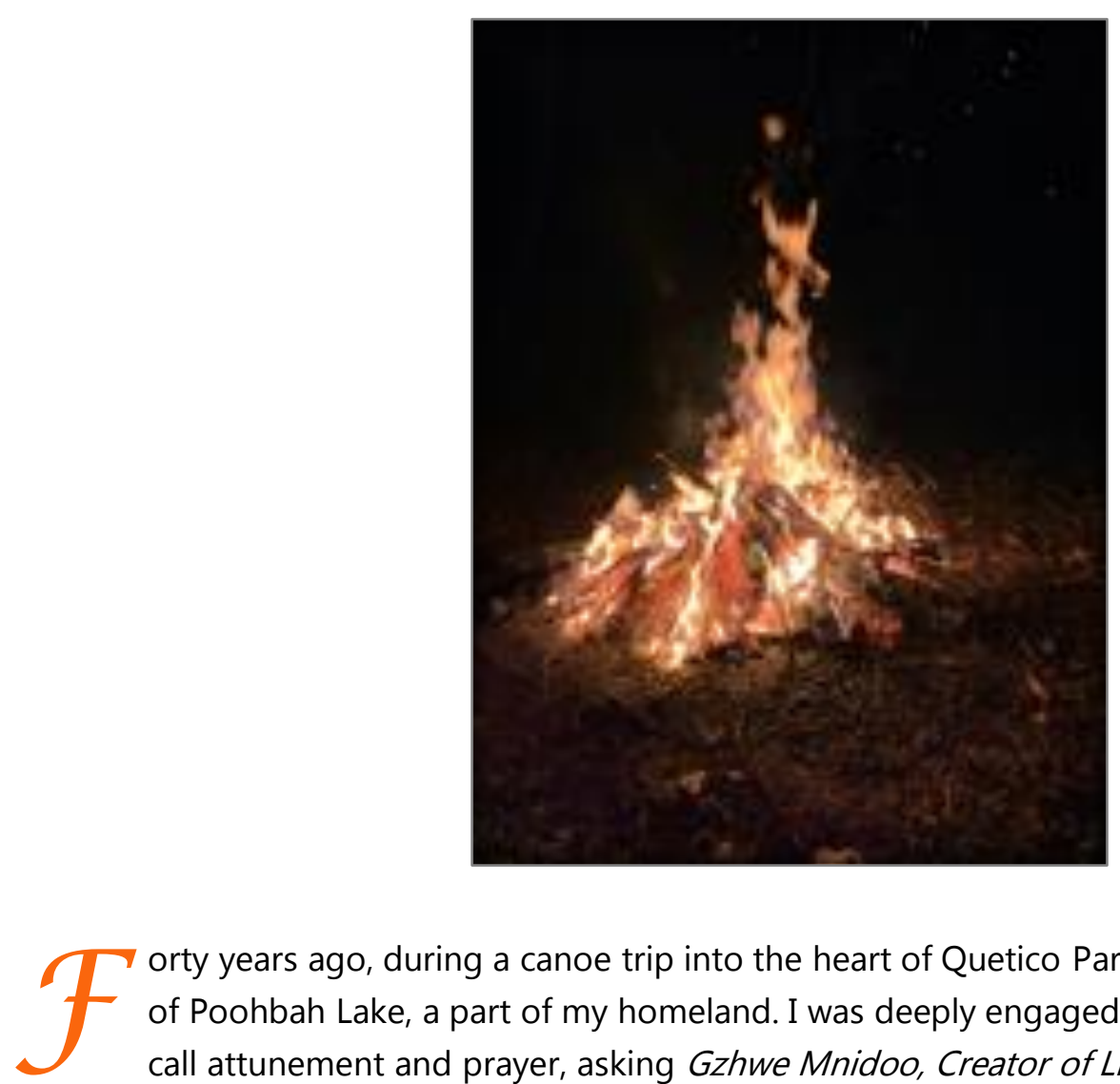

orty years ago, during a canoe trip into the heart of Quetico Park, I was sitting on the shores of Poohbah Lake, a part of my homeland. I was deeply engaged in a process I would now call attunement and prayer, asking Gzhwe Mnidoo, Creator of Life's Essence, or the Great Mystery, and my Ancestors to guide me on my way. I was in my twenties, and I wondered how I would walk my life's journey and honour the teachings of Mino Bimaadiziwin, or the Red Road to the Good Life as understood by my Ancestors. What would be my life's work as I endeavoured to enact Kizhay Ottiziwin: to be one who walks gently, humbly, in a peaceful way? I longed to be a living being of kindness and useful to my kin, All My Relations. Kizhay means to live, act, from the heart, Ottiziwin to walk in the spirit of the Creator, Gzhwe Mnidoo.

As my moccasined feet gently walked the land, I wanted to better understand the code I knew: to honour each and everything as created, to open my heart, and to regard each being with reverence and respect. I learned to hold these teachings as they were offered. As I grew older, I understood the enormous gift I was given to witness Creation as it had been created by Gzhwe Mnidoo in all its pristine majesty. This witnessing also fostered a sensitivity within me and actively shaped my being and flute playing as instruments for perceiving and knowing. I experienced the land before it was logged and plundered for what it held. I would often venture out onto the land only to come across a whole section of the forest that had been clear cut, leaving only a thin veneer of trees along the shore of the lake. During my adolescence, beautiful forests north of the Trans-Canada Highway were gradually clear cut leaving only a tangle of stumps and roots where once dense ecologies of life had been. This learning legacy seared itself into my mind, heart and spirit. Over time 
and through travel, I began to more fully recognize the gift I was given; it was a profound and powerful inheritance and with it came an enormous responsibility. As I wander my life journey, I feel impelled to return to the teachings of my people, the Anishinaabe, longing to find an honourable way to walk this earth. This Indigenous métissage tells the story of my search, my Biskaabiiyang or returning to the teachings of Mino Bimaadiziwin, the pathway to the good life through the practice of Kizhay Ottiziwin. This longing has been with me throughout my life, yearning for another vision of how to be a good relative to All My Relations. I, like other Indigenous scholars of my generation, have taken up the work of turning and walking back along the trail left by our Ancestors. As Robin Wall Kimmerer (2013) suggests,

The People of the Seventh Fire do not yet walk forward; rather, they are told to turn around and retrace the steps of the ones who brought us here. Their sacred purpose is to walk back along the red road of our ancestors' path and to gather up all the fragments that lay scattered along the trail. Fragments of land, tatters of language, bits of songs, stories, sacred teachingsall that was dropped along the way. Our elders say that we live in the time of the seventh fire. We are the ones the ancestors spoke of, the ones who will bend to the task of putting things back together to rekindle the flames of the sacred fire, to begin the rebirth of a nation. (pp. 367-368)

So, I turned and walked back along the trail of my ancestors, I took long solo kayak trips along the shores of Lake Nipigon and Lake Superior, I took up the Native American flute, and made pilgrimages into the lands of the Navajo, Lakota and Hopi people to learn from the discipline of wind, and played in canyons. I did a two-year apprenticeship in Northwest Coast Art learning through traditional painting, traditional carving and walking in the landscapes of Northern British Columbia, how the stories and the artforms created living re-presentations of whole cosmologies, knowledges, cultural traditions and ceremonies. Through these experiences, I learned that it is the reanimation of an ancient cosmology, the worldview of the Anishinaabe people (Cajete, 2015) and its imagination, which has offered the teachings that have resounded and resonated within me. This also became the focus of my Indigenous inquiry as I took up artistic practices through which I have engaged in the pedagogical pathway created by these Indigenous knowledges, practices and ceremonies. These processes have transformed me over time and helped me become attuned to the environmental and spiritual ecologies (Cajete, 1994) of my people, the Anishinaabe. I gradually became aware that my way of knowing and being was being transformed, and I was learning to hold these experiences and knowledges with different hands. For to theorize means to behold, to hold with being. My being was learning how to hold these teachings as they were given so, as I picked up a story, a song, an art practice, or a bit of the language, I had to learn how to hold them within me. I gradually understood how the knowledge holders of the present are holding the echoings or the gifts of our Ancestors. And in order to learn to resonate with the bits of teaching left along the way, we have to learn how to hold the knowledges as they are given. Through these pedagogies left by our Ancestors we are transformed and undergo a humble metamorphosis in order to be useful to the work placed before us. 
Why do I and many other scholars and educators walk back along the trail of our Ancestors? What is our sacred intention? How do we learn to hold the teachings of our Ancestors such that they are useful for our times? Again, I think Kimmerer (2013) speaks to our sacred intent:

What does it mean to be people of the seventh fire, to walk back along the ancestral road and pick up what was left behind? How do we recognize what we should reclaim and what is dangerous refuse? What is truly medicine for the living earth, and what is the drug of deception? None of us can recognize every piece, let alone carry it all. We need each other, to take a song, a word, a story, a tool, a ceremony and put it in our bundles. Not for ourselves, but for the one yet to be born, for all our relations. Collectively, we assemble from the wisdom of the past a version for the future, a worldview shaped by mutual flourishing. (p. 371)

This is ultimately the spirit of my intent, to be useful to those who will follow. In my world, the Ancestors stand behind me and the future generations stand before me; thus, I feel great responsibility to be useful to both. I have chosen to work with the teachers of the next generation in the area of Indigenous education. It is through my own Indigenous inquiry that I have come to understand possible pedagogies for honouring each of our intents to find Mino Bimaadiziwin. Thus, I have looked for stories, teachings and Indigenous knowledge practices that offer us pedagogical pathways for this sacred transformation of our humanness.

Through my work in teacher education, I have come to understand there are many others who experience a profound cultural dissonance with our times and are also looking for another vision; they long to reach for a dream of the possible, of new and renewed ways of walking that will serve them and the young ones they work with. So, I have been looking for practices and processes in the spirit of shkitagen, the traditional firekeeper gathered from our tree of life, the Birch Tree. I have struggled to find ways that lead to wellness and healing in the midst of my responsibilities for reconciling, restoring and reanimating the teachings of my Ancestors and in finding what is useful and serves a resurgence of my peoples' cultural ways and knowledges. What are the medicines for the reconciling and healing with our human and more than human relatives? What process and practices can we gather in our medicine bundles as we walk bravely into the future midst the climate crisis and the crisis of relations with our human relatives. Again, Kimmerer (2013) speaks to this journey we are on collectively:

As the seventh fire people walk the path, we should all be looking for Shkitagen, the ones who hold the spark that cannot be extinguished. We find the firekeepers all along the path and greet them with gratitude and humility that against all odds, they have carried the ember forward, waiting to be breathed into life. In seeking the shkitagen of the forest and shkitagen of the spirit, we ask for open eyes and open minds, hearts open enough to embrace our morethan-human kin, a willingness to engage intelligences not our own. We'll need trust in the generosity of the good green earth to provide this gift and trust in human people to reciprocate. I don't know how the eighth fire will be lit. But I do know we can gather the tinder that I will nurture the flame, that we can be shkitagen to carry the fire, as it was carried to us. Is this not a holy thing, the kindling of this fire? So much depends on the spark. (p. 373) 
The possibility of and responsibility for lighting of the Eighth Fire lies before us all. Will we find a way to transform our systems of education and justice to restore ecological sustainability? And how can we transform ourselves such that we are useful to this task? I humbly offer my story of transformation and attunement. In the following Indigenous Métissage (Donald, 2012), I weave Aandisokaanan (traditional sacred stories), like the Anishinaabe Creation stories, with Dibaajimowinan (personal stories), teachings gained through walking the road to Mino Bimaadiziwin (the good life). These are woven with a third strand that tells the story of how these stories and teachings led to the development of a pedagogical pathway, a way of walking in the world, seeking to attune to the world in a way that honours All Our Relations. I share how I have found ways to ignite the spark within myself, and then I humbly offer these practices and processes to others along the way. In the spirit of Cajete (2015), who says it is through our Creation stories that we learn to find our way as Indigenous peoples, I offer forward a sacred version.

Without being able to follow our footprints back to a Creation Story that accounts for where we and all the beings and all the elements that are Creation come from, we have no way to understand how that ecology is asking us to develop an intelligence that is symmetrical with all of Creation. When all things spoke to all things, ecology and story were simultaneous and symmetrical expressions of each other. (Cajete, 2015, p. 377)

The following is an Aandisokaanan, a teaching story, that is resonant with what is currently found in print and offered by authors such as Nicole Bell and others of the Toronto Zoo Ways of Knowing Partnership Turtle Island Conservation Programme (2010), Edward Benton-Banai (1988), Basil Johnston (1976) and Leanne Simpson (2011). However, I have significantly shortened the retelling to fit within the context of this article. The Creation story I am about to retell is known as the Seven Fires of Creation, and each of the seven stages of Creation took eons of time.

\section{Seven Fires of Creation}

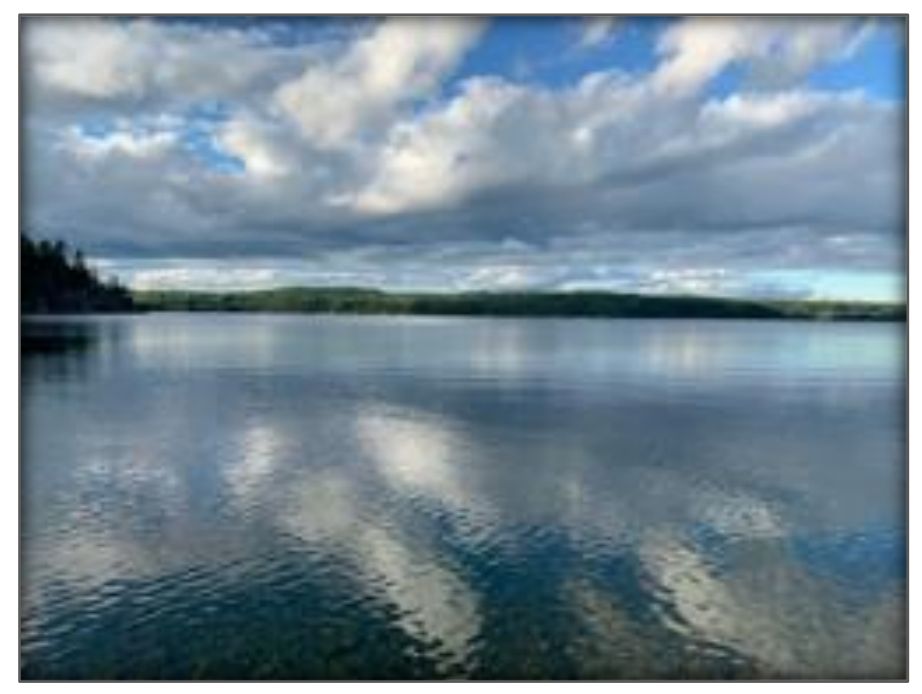


In the beginning, there was only darkness, emptiness, silence and cold. It went on and on forever and without boundaries. Somewhere in the darkness a sound was heard, a sounding like the rumbling of thunder heard far, far in the distance. After an unimaginably long silence, the sounding appeared again, and it seemed closer. Each time the sounding appeared it was followed by long periods of silence. Each time it seemed closer until there was a mighty flash of light and the deafening sound of thunder. This was also followed by deep silence. After a long pause of silence there appeared a shimmering sound like the shaking of seeds in a gourd. This was heard everywhere in the endless darkness. The understanding is that the shimmering shaking seedlike sounds were the thoughts of the Gzhwe Mnidoo. There was also another sound, a different kind of sound, a feeling sounding in the centre of the darkness. In the centre of the vast darkness a rhythm was generated. It was the heart throb at the centre of all that was to be. It moved out from a centre in great rhythmic, concentric circles filling the whole void. So, thoughts sounded like the shimmering shaking of seeds that reverberated in the darkness and the rhythm of the heartbeat created resonating circles of sound from the centre of Creation. This was the first Fire of Creation.

When I learned of this teaching, I was deeply moved. I had become a Native flute player and, through this practice of playing my flute out on the land, I was developing a capacity for deep listening. I was learning to strain, to tune myself, and entrain with the sonic ecologies of place. I now understand that I was tuning to attuning with the circle of being within a place, and the reverberating echoing I heard was the feeling like a re-sounding echoing through time. Over time, I became more awake and sensitive to these acoustic ecologies and their echoings. I was gradually tuning my being and over time learning to be more profoundly resonant.

There is another moment I have summarized in the Creation story that speaks to what we are attuning to through Indigenous knowledge practices:

Within the great circle of the universe Gzhwe Mnidoo created the Second Fire, Giizis the Sun, along with the Third Fire, Grandmother Moon, creating the duality of night and day. With the Fourth Fire, the four sacred directions and all Creation were brought into movement. With the Fifth Fire, Gzhwe Mnidoo fashioned the seeds of Creation, filled with the thoughts, creative energy and all the intended potential for life. Then she/he called the beneshiinyak, birds of every colour, size, shape and song. Gzhwe Mnidoo then made a place for all these seeds of potential becoming. The place for this emerging Creation was to be with the beautiful and bountiful Mother Earth. Gzhwe Mnidoo gave her a heart created from the First Fire and placed it in the core of her being. When the sacred seeds were scattered on Mother Earth, life sprang forth in all its multiple forms, everything moved in harmony and balance. Gzhwe Mnidoo was so filled with joy that tears fell to Mother Earth, and all was showered with love. From the breast of Mother Earth came all that there is and that there will be. The winged of the air, the swimmers, the four legged and the crawlers, the flowers and trees, and the great seas that move between the lands. All were created from seeds fashioned by Gzhwe Mnidoo. This was the Sixth Fire of Creation. 
Gzhwe Mnidoo then created the Original Human. This being was fashioned from earth, water, air and fire, into which was breathed the spirit breath of life. Gzhwe Mnidoo touched his/her forehead and gave the Original Human all the thoughts that went into the fashioning of Creation, and these thoughts were so vast they flowed out his/her head and into his/her entire body. Then Gzhwe Mnidoo touched Original Human's breast causing his/her heart to beat in harmony with the rhythm of the universe and with the heartbeat of Gzhwe Mnidoo. Then the Original Human was lowered down to become a child of Mother Earth so that he/she may learn from all of Creation teachings on being human and how to be a good relative.

It is this moment when the Original Human is lowered to Mother Earth, a yearning filled him/her to be a humble part of Creation, to be as all the other beings were seen and felt as they moved about on the earth. He/she was filled by a desire to be at home in this world and to be a part of the great harmony and balance of life. Seeing the strength and beauty of all that was created on earth, he/she desired to be of this earth and belong within the family of Creation. So, it is said that as he/she approached the earth, he/she reached out and pointed his/her toes so that somehow, if at all possible, when he/she touched down he/she would do no harm or crush the smallest blade of grass, the tiniest flower, or the smallest living creature that crawled upon the earth. Longing to come down amidst all Creation and to be a living, loving part of all that is, is how the Original Human Being or Anishinaabe, the one who was lowered to earth, touched down upon Mother Earth. And from that time, Anishinaabe has always known his/her Mother and always felt his/her kinship with the family of Creation. Through Anishinaabe flows the spirit, life force, thoughts and heartbeat of Gzhwe Mnidoo and this also comes with the longing to reflect back to the Creator, Gzhwe Mnidoo's intention by making Anishinaabe in his/her image and lowering him/her to Mother Earth.

I share this Creation story with you because it holds within it images of an Anishinaabe worldview and cosmology, along with Anishinaabe teachings about the world and how to be a good relative to All One's Relations. It holds encoded within the images a pathway to becoming fully human. There are three moments, or Fires of Creation, that have profoundly impacted me and my pedagogical practice. The first is the understanding that Creation began in sounding acoustically, and that in this reverberating sounding lived the mind and heart of Gzhwe Mnidoo. Culturally, we also acknowledge this moment in ceremony through the use of the sacred rattle, honouring the shimmering shaking seeds of Creation.

The second moment that moves me acknowledges that, as humans, we are made from or hold the thoughts of the Creator and all Creation. We have beating within us the heartbeat of the Creator as well as the heartbeat of Creation. To be attuned to Creation is to entrain with the sounding rhythms and echoes of the created world - to resound with both the acoustic sound of the listening ear as well as the felt sound or resonance as perceived by the open heart. This teaching is culturally honoured in the sounding of the sacred drum in ceremony, the heartbeat of Creation and Mother Earth, that causes our bodies, hearts and minds to thrum with its pulsing resonance; it teaches us to attune to the reverberations, to entrain with the energy that ultimately unites all beings of Creation. 
Humans have the ability to perceive this creative energy and original intention of the teachings of Creation. Within our thoughts live the teachings that are fashioned like seeds within Creation because we were also gifted with these thoughts as well. This is an active part of our tuning or entraining with Mother Earth and All Our Relations. And when we open our hearts, we feel united to the cosmic heartbeat of Creation. We sing and through our sounding become both the instrument and the song.

The third moment is during the lowering of the Original Human or Anishinaabe toward the earth. Not only does the vision of Mother Earth and the community of life arising before me inspire profound humility, but as my foot, my soul as my sole, touches the earth, I am touched by deep gratitude for her beauty and bounty. Each and every being has a place and also a teaching to share with us as we make our way towards the fullest possible expression of ourselves. The moment that fascinates me most is the moment when Anishinaabe stretched out a foot to touch down as gently and carefully as possible. This feeling of profound reverence and deepest respect permeates the sole of each foot that caresses Mother Earth when reaching with their toes upon touching down, landing gently on the breast of Mother Earth.

Perhaps it is an echo of this that I experience when I walk with my moccasins or mukluks in the woods. My feet develop an awareness for touching the earth with humility, love and gratitude. I often feel as though I am walking in a sacred place. I can feel the pulsing life through the soles of my feet, and this causes my soul to entrain and resound. In my singing soul is sounding an echo of the teachings of my Ancestors and Mother Earth.

This longing for Kizhay Ottiziwin (to walk with kindness and kinship) began when I was a child and has only grown over time. However, it was also tempered by what I witnessed growing up through the destruction of the sacred ecology of Creation as it was intended by Gzhwe Mnidoo. I witnessed the clear cutting of all the forests within my homeland leaving mere margins remaining along the lakes like a facade for what was once a sacred ecology of being. I witnessed the resource extraction of mining that scarred the face of Mother Earth. And All My Relations fled to find safety and sanctuary with the depletion and destruction of their habitat. Over time, I felt impelled to find a way, to seek out the good road to wellbeing for myself and to find the medicines to heal the wounds I witnessed. I wanted to be useful to the generations to come. 


\section{Offering Forward: People of the Eighth Fire}

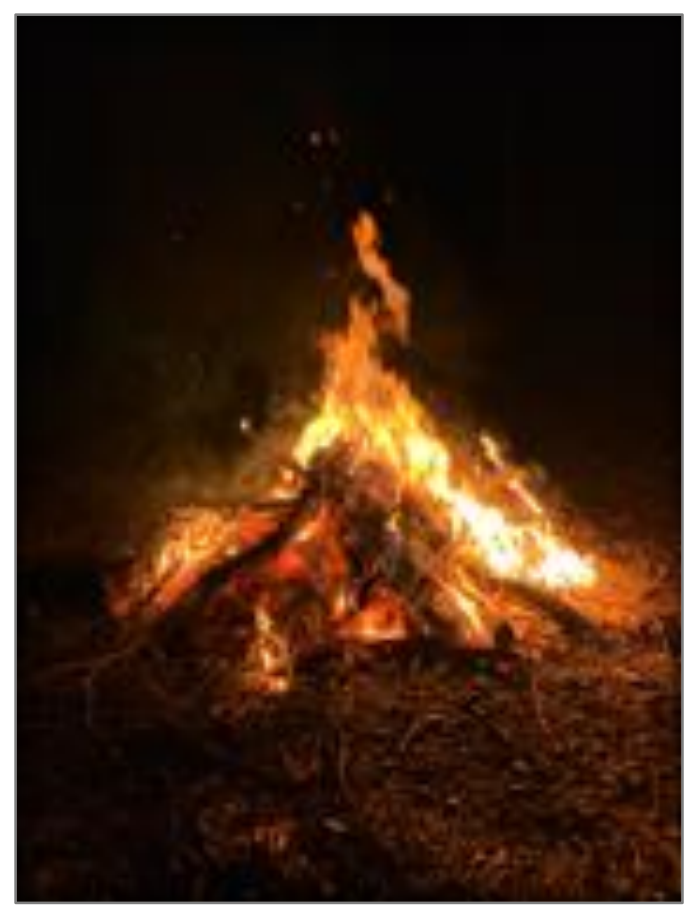

I have found pedagogical pathways through story and song, but also through traditional land practices and Indigenous making processes like gathering and preparing medicines, weaving, carving, drumming, and participating in ceremony. As I came to understand the nature of these participatory pedagogies, I offered them to students and invited them to find and take up their own practices to make and un-make themselves such that they become resonate beings attuned to the ecologies in which they live. They make drums, learn songs from the local Nations, learn to a/tune as they walk the land to receive the teachings from All Their Relations. They write their stories of learning and becoming within the creation of their Métissage (Hasbe-Ludt, 2009), weaving their life writings and their artistic creations as they discover their own teachings within their Dibaajimowinan, personal stories, and find their own Debwewin, or truth to live by. They develop visions of a possible pathway to a good life or Mino Bimaadizowin. It has become clear that Métissage offers them a curricular pathway to reconcile their life journey with their educational practice. As they braid their personal stories with the stories of their students, they create texts woven with stories of reconciliation, acknowledge sites of resistance and restoration and dream a vision of resurgence and healing.

Drawing support from Dwayne Donald (2012), I also maintain that theorising Métissage as a curricular practice can be used to resist the priority and authority given to official texts and textural practices. It offers us another pathway of attunement to our individual and collective affinities:

This curricular form of métissage shows how personal and family stories can be braided in with larger narratives of nation and nationality, often with provocative effects. Thus, rather that viewing métissage as solitary research, this form of métissage relies on collaboration and 
collective authorship as a strategy for exemplifying as text and research praxis, the transcultural transdisciplinary and shared nature of the experience and memory. Metissage, in this example, calls authors to work "collectively to juxtapose their text in such a way that highlights difference (racial, cultural, historical, socio-political and linguistic) without essentializing or erasing it, while simultaneously locating points of affinity" (Chambers et al., 2008, p. 142). (Donald, 2012, p. 537)

Through their engagement with Indigenous pedagogies and practices, and through the creation of their Métissage, the students deepened their intent in finding ways of being and knowing that honour their learning spirits and is useful to the future generation sitting before them in their classrooms. They offer their students pedagogies of attunement, and practical pathways to honouring their students longing to become endogenous or indigenous to Mother Earth. They teach others how to visit with the land, to dwell within their places, and to honour the teaching of these diverse ecologies. To walk with kindness, such that the soles of their feet honour their souls longing to do no harm and to be a good relative to all of Creation.

This pedagogical process of attunement has enabled me and others to walk well with kindness, honouring our kinship with all of Creation. By returning to the teachings through the processes of Biskaabiiyang, the teachings of my Anishinaabe Ancestors have tuned my imagination to the land such that I am now awakened to the perception of the sounding ecologies in which I dwell. I have taken deeply to heart the words of Sheridan and Longboat (2006) and found a way to attune my imagination to the land and to walk with a living sensibility, the capacity to be resonating, entraining with the living sounding that gave rise to Creation since the beginning of time.

Imagination has a place because imagination is a place, and because everything is connected to everything else, the encounter with the imagination is a living communication within a sentient landscape ... where one is has everything to do with who one is... When mind, spirit and land ... are understood to be as they have always been, as coevolutionary, there emerges a principle that guides imagination in its duty to integrate nature's realities and ensure the perpetuation of those realties and so all of Life. (Sheridan \& Longboat, 2006, p. 370)

It is my hope that we will collectively take on the work of reimagining our worlds such that they are indeed attuned to the creative intention that sounded forth like thunder at the beginning of time and shimmered in the shaking seeds of being that gave rise to it all.

Biskaabiizang: May we turn and walk back along the path of our Ancestors to restore and reanimate the teachings of All Our Relations.

Kizhay Ottiziwin: May we walk with kindness and kinship and may we find Mino Bimaadiziwin.

Chi Miigwech, All My Relations. 


\section{About the Author}

Vicki Kelly is Anishinaabe/Métis and an Indigenous scholar in the Faculty of Education at Simon Fraser University. She works in the areas of Indigenous, ecological and art education. Her research foci are Indigenous knowledges, pedagogies and cultural resurgence. She plays the Native American flute and is a visual artist, carver and writer.

\section{References}

Benton-Banai, E. (1988). The Mishomis book: The voices of the Ojibway. University of Minnesota Press.

Bell, N. E., Conroy. K, Wheatley, B., Michaud, C., Maracle, J., Pelletier, B., Filion, B., \& Johnson, B. (2010). The ways of knowing guide. The ways of Knowing Partnership Turtle Island Conservatory, Toronto Zoo.

Cajete, G. (1994). Look to the mountain: An ecology of Indigenous education. Kivaki Press.

Cajete, G. (2015). Indigenous community: Rekindling the teachings of the seventh fire. Living Justice Press.

Donald, D. (2012). Indigenous métissage: A decolonizing research sensibility. International Journal for Qualitative Studies in Education, 5(5), 533-555.

Hasebe-Ludt, E., Chambers, C., Leggo, C. (2009). Life writing and literary métissage as an ethos for our times. Peter Lang.

Johnson, B. (1976). Ojibway heritage. McClelland \& Stewart.

Simpson, L. (2011). Dancing on our turtle's back: Stories of Nishnaabe re-creation, resurgence and a new emergence. Arbeiter Ring.

Sheridan, J., \& Longboat, R. (2006). The Haudenosaunee imagination and the ecology of the sacred. Space and Culture, 9(4), 365-381.

Kimmerer, R. W. (2013). Braiding sweetgrass: Indigenous wisdom, scientific knowledge and the teachings of plants. Milkweed Editions.

\section{Endnote:}

The images used in this paper are the author's photographs and are used with permission. 